\title{
Comparative evaluation of phytochemicals in the raw and aqueous crude extracts from seeds of three Lablab purpureus varieties
}

\author{
Soetan K. O. \\ Department of Veterinary Physiology, Biochemistry and Pharmacology, University of Ibadan, Nigeria. \\ E-mail: soetangboye@yahoo.com.
}

Accepted 30 July, 2012

\begin{abstract}
The phytochemicals in the raw and aqueous crude extracts from seed of three varieties of Lablab purpureus (LP), including Rongai brown, Rongai white and Highworth black were comparatively evaluated as a preliminary study for their pharmacological potential. The phytochemicals analyzed were trypsin inhibitors, hydrogen cyanide, oxalate, haemagglutinin units, phytate, tannin, saponin and alkaloids. The study concluded that raw (LP) contained higher concentration of phytochemicals than the aqueous crude extracts of (LP) in the three varieties studied.
\end{abstract}

Key words: Phytochemicals, Lablab purpureus, pharmacological, crude extract.

\section{INTRODUCTION}

Lablab purpureus (lablab beans) is an under-utilized legume that has potential as human food (Bawa et al., 2003). It is a legume that thrives well during the dry season between November and February in Northern Nigeria. It is drought resistant and is usually sown after the normal cropping season, thereby acting as a buffer crop for ruminant feeding during the dry season (Adu et al., 1992). L. purpureus is reported to have certain medicinal properties (Handa et al., 1989; Adeleke et al., 2012). Phytochemicals include secondary metabolites of plants, and other antinutritional factors, which are reported to be pharmacologically active (Zank, 1991). Several reports have provided evidence for the pharmacological effects of plant phytochemicals. Tannins are reported to have anthelmintic effects (Molan et al., $2000 \mathrm{a}$, b) and useful in the treatment of inflamed or ulcerated tissues and they also have remarkable activities in the cancer prevention and anticancer activity (Akinpelu et al., 2009). Flavonoids, phenols and saponins have been reported to exhibit their actions through effects on membrane permeability, antioxidative action and antiinflammatory effects (Olayinka and Okoh, 2010). Many triterpene saponins and their aglycones have varied uses including anti-inflammatory, antipyretic, fibrinolytic, analgesic, anti-ulcerogenic, anti-oedema and antimicrobial agents (Hostettmann and Martson, 1995; Soetan et al., 2006; Ndukwe et al., 2007). Alkaloids are haemolytically active, toxic to micro-organisms and are widely used as therapeutic agents in the management of cancer (Viji and Parvatham, 2011). Glycosides are reported to inhibit tumour growth and to also protect against gastrointestinal infections (Adeshina et al., 2010). Terpenoids have been reported to be active against bacteria, fungi, protozoa and virus (Maiyo et al., 2010). El-Mahmood et al. (2008) linked antimicrobial properties of plants to bioactive secondary metabolites (saponins, tannins, alkaloids, flavonoids, phenols, glycosides and diterpenes).

Due to the discovery of the beneficial effects of phytochemicals in food plants, this study was designed to evaluate the concentration of various phytochemicals in L. purpureus, which could be a guide to ascertain their pharmacological potentials. The phytochemicals to be evaluated are trypsin inhibitors, haemagglutinins, cyanogenic glycosides, oxalates, phytates, tannins, saponins and alkaloids.

\section{MATERIALS AND METHODS}

Source of L. purpureus

The three varieties of raw $L$. purpureus seeds used for this study were Rongai white (NAPRI 4), Rongai brown $\left(P_{1} 509114\right)$ and Highworth black (Grif 12293). They were obtained from the 
International Institute of Tropical Agriculture (I.I.T.A.) Ibadan, Nigeria.

\section{Extraction of the aqueous crude extract}

Dried raw lablab seeds (150 g) were weighed and ground using a clean electronic grinder. Then $400 \mathrm{ml}$ of distilled water was added to the ground seeds. The solution was allowed to stand for $6 \mathrm{~h}$ in distilled water, with regular stirring and was filtered using cheese cloth. The filtrate was then placed in a water bath at $60^{\circ} \mathrm{C}$ for $6 \mathrm{~h}$ to allow for evaporation of the water in the extract. The phytochemicals in the extract were then evaluated.

\section{Quantification of the phytochemicals}

The phytochemicals in the three varieties of the raw and aqueous crude extract of $L$. purpureus were quantified using standard methods.

\section{Determination of trypsin inhibitor activity}

Trypsin inhibitor activator of the samples were determined by the method of Liener (1979). $0.2 \mathrm{~g}$ of each sample was weighed into a screw-cap centrifuge tube. $10 \mathrm{ml}$ of $0.1 \mathrm{M}$ phosphate buffer was added and the contents were shaken at room temperature for $1 \mathrm{~h}$ on a UDY shaker. The suspension obtained was centrifuged at $5000 \mathrm{rpm}$ for $5 \mathrm{~min}$ and filtered through Whatman No.42 filter paper. The volume of each was adjusted to $2 \mathrm{ml}$ with phosphate buffer. The test tubes were placed in water bath, maintained at $37^{\circ} \mathrm{C}$ and $6 \mathrm{ml}$ of $5 \%$ tricarboxylic acid (TCA) solution was added to one of the tubes to serve as a blank. $2 \mathrm{ml}$ of casein solution was added to all the tubes previously kept at $37^{\circ} \mathrm{C}$ and were incubated for $20 \mathrm{~min}$. The reaction was stopped after $20 \mathrm{~min}$ by adding $6 \mathrm{ml}$ of TCA solution to the experimental tubes and then shaken. The reaction was allowed to proceed for $1 \mathrm{~h}$ at room temperature. The mixture was filtered through Whatman No.42 filter paper and the absorbance of filtrate from sample and trypsin standard solutions were read at $280 \mathrm{~nm}$.

\section{Determination of haemagglutinin level}

Haemagglutinatinin level of the samples were determined by the method of Jaffe (1979). $2 \mathrm{~g}$ of each sample was weighed and $50 \mathrm{ml}$ of solvent of mixture of isobutyalcohol and trichloroacetic acid were added and allowed to shake on a UDY shaker for $6 \mathrm{~h}$ to extract the haemagglutinin. The mixture was filtered through a double layer filter paper and maintained in a water bath for $2 \mathrm{~h}$ at $80^{\circ} \mathrm{C}$ and the filtrate was allowed to cool. A set of standard solutions of haemagglutinin ranging from 0 to $10 \mathrm{ppm}$ were prepared from the haemagglutinin stock solution. The absorbances of the standard solution as well as that of the filtrate were read at $220 \mathrm{~nm}$ on a digital spectrophotometer 21D.

\section{Determination of hydrocyanic acid}

The hydrocyanic acids ( $\mathrm{HCN})$ of the samples were determined using the procedure of Bradbury et al. (1999). $5 \mathrm{~g}$ of each sample was weighed and each sample was incubated for another $16 \mathrm{~h}$ at a temperature of $38^{\circ} \mathrm{C}$. After the extraction, the filtration was done using a double layer of hardened filter paper. The distillation was done with Markham distillation apparatus. Each sample extracted was transferred into a two-necked $500 \mathrm{ml}$ flask connected with a steam generator. This was steam-distilled with saturated sodium bicarbonate solution contained in a $50 \mathrm{ml}$ conical flask for $60 \mathrm{~min} .1$ $\mathrm{ml}$ of starch indicator was added to $20 \mathrm{ml}$ of each distillate and was titrated with $0.2 \mathrm{~N}$ of iodine solution.

\section{Determination of oxalate}

The total oxalates were determined according to the procedure of Fasset (1996). The extraction was done by weighing $1 \mathrm{~g}$ of each sample and soaked with $100 \mathrm{ml}$ of distilled water. These were allowed to stand for $3 \mathrm{~h}$ and each was filtered through a double layer of filter paper. 10, 20, 30, 40 and $50 \mathrm{ppm}$ standard solution of oxalic acid were prepared and read on the spectrophotometer at $420 \mathrm{~nm}$ for the absorbance. The absorbances of filtrate from each sample were also read on the spectronic 20.

\section{Determination of phytate}

Phytates were determined using the method of Maga (1983). $2 \mathrm{~g}$ of each sample was weighed. $100 \mathrm{ml}$ of $2 \%$ concentrated hydrochloric acid was used to soak each sample into conical flask for $3 \mathrm{~h}$ and filtered through a double layer of hardened filter paper. $50 \mathrm{ml}$ of each filtrate was placed in $250 \mathrm{ml}$ beaker and $107 \mathrm{ml}$ of distilled water was added in each case to give proper acidity. $10 \mathrm{ml}$ of $0.3 \%$ ammonium thiocyanate solution was added into each solution as indicator. This was titrated with standard iron (III) chloride solution which contained $0.00495 \mathrm{~g}$ iron per $\mathrm{ml}$. The end point was slightly brownish-yellow which persisted for $5 \mathrm{~min}$.

\section{Determination of tannin content}

Tannins were determined using the method of Dawra et al. (1988). $0.2 \mathrm{~g}$ of each sample was weighed into a beaker. Each was soaked with solvent mixture $(80 \mathrm{ml}$ of acetone and $20 \mathrm{ml}$ of glacial acetic acid) for $5 \mathrm{~h}$ to extract tannin. The filtrates were removed and the samples were filtered through a double layer filter paper to obtain the filtrate. A set of standard solution of tannic acid was prepared ranging from 0 to $10 \mathrm{ppm}$. The absorbances of the standard solution as well as that of the filtrates were read at $720 \mathrm{~nm}$ on a spectronic 20.

\section{Determination of saponin}

Saponins were determined using the procedure of Brunner (1984). $2 \mathrm{~g}$ of sample was weighed and $100 \mathrm{ml}$ of isobutylalcohol (octanol) was added and left for $5 \mathrm{~h}$ on a UDY shaker for uniform mixing to obtain a uniform solution. The mixture was then filtered through a No.1 Whatman filter paper. The filtrate was transferred and was saturated with magnesium carbonate solution. The mixture was transferred into $100 \mathrm{ml}$ volume flask and made up to mark with distilled water. The mixture obtained here was then filtered to obtain a clear colourless solution to be read on a spectrophotometer at $380 \mathrm{~nm}$. 0 to $5 \mathrm{ppm}$ of standard saponin solutions were prepared from 1000 ppm saponin stock standard solution and saturated with magnesium carbonate as above and also filtered. The absorbances of the saponin standard solution (that is, $0-5 \mathrm{ppm}$ ) were also read at $380 \mathrm{ppm}$ to obtain the gradient of plotted curve.

\section{Determination of alkaloids}

Alkaloids were determined using the procedure of Henry (1973). $2 \mathrm{~g}$ of sample was weighed and $20 \mathrm{ml}$ of $80 \%$ alcohol was added to give a smooth paste. The mixture was transferred and more alcohol was added to give up to $100 \mathrm{ml}$. $1 \mathrm{~g}$ of magnesium oxide was 
Table 1. Phytochemicals in the three varieties of raw L. purpureus seeds.

\begin{tabular}{|c|c|c|c|c|c|c|c|c|}
\hline Sample & $\begin{array}{c}\text { Trypsin inhibitors } \\
(\mathrm{U} / \mathrm{mg}) \\
\text { protein }\end{array}$ & $\begin{array}{l}\text { Haemagglutinins } \\
(\mathrm{U} / \mathrm{mg})\end{array}$ & $\begin{array}{c}\text { Cyanogenic } \\
\text { glycosides } \\
(\mathrm{mg} / \mathrm{kg})\end{array}$ & $\begin{array}{l}\text { Oxalates } \\
(\mathrm{mg} / \mathrm{g})\end{array}$ & $\begin{array}{l}\text { Phytates } \\
(\mathrm{mg} / \mathrm{g})\end{array}$ & $\begin{array}{l}\text { Tannins } \\
(\mathrm{mg} / \mathrm{g})\end{array}$ & $\begin{array}{l}\text { Saponins } \\
(\mathrm{mg} / \mathrm{g})\end{array}$ & $\begin{array}{l}\text { Alkaloids } \\
\text { (mg/g) }\end{array}$ \\
\hline Rongai brown & $44.8 \pm 0.57^{\star}\left({ }^{* \star}\right)$ & $23.7 \pm 0.10^{*}$ & $185 \pm 0.89^{*}$ & $9.3 \pm 0.36^{*}$ & $13.6 \pm 0.27^{*}$ & $4.7 \pm 0.06$ & $11.3 \pm 0.17^{\star}\left({ }^{\star *}\right)$ & $4.8 \pm 0.12^{*}$ \\
\hline Rongai white & $\left.31.6 \pm 0.21^{\star * *}\right)$ & $18.7 \pm 0.17^{\star}\left(^{\star *}\right)$ & $175 \pm 0.00^{*}\left({ }^{* *}\right)$ & $8.2 \pm 0.12\left({ }^{* \star}\right)$ & $14.4 \pm 0.06\left(^{* \star}\right)$ & $3.5 \pm 0.84$ & $11.6 \pm 0.06^{\star}$ & $3.7 \pm 0.15^{\star}\left(^{* *}\right)$ \\
\hline Highworth black & $39.5 \pm 0.29$ & $28.6 \pm 0.06^{*}\left(^{* *}\right)$ & $195 \pm 0.57^{*}\left({ }^{* \star}\right)$ & $9.8 \pm 0.17$ & $14.0 \pm 0.00$ & $4.2 \pm 0.81$ & $12.1 \pm 0.06^{*}\left(^{* *}\right)$ & $6.8 \pm 0.15^{\star}\left(^{\star *}\right)$ \\
\hline
\end{tabular}

Most of the values were significant at $p<0.05^{*}$, 'Statistical significance among groups using $F$ test, ${ }^{*}$ Statistical significance between groups at $p<0.05$ using ' $t$ ' test.

Table 2. Phytochemicals in the aqueous crude extracts of three varieties of $L$. purpureus seeds.

\begin{tabular}{|c|c|c|c|c|c|c|c|c|}
\hline Sample & $\begin{array}{c}\text { Trypsin } \\
\text { inhibitors }(\mathrm{U} / \mathrm{mg}) \\
\text { protein }\end{array}$ & $\begin{array}{l}\text { Haemagglutinins } \\
\text { (U/mg) }\end{array}$ & $\begin{array}{l}\text { Cyanogenic } \\
\text { glycosides } \\
(\mathrm{mg} / \mathrm{kg}) \\
\end{array}$ & $\begin{array}{l}\text { Oxalates } \\
(\mathrm{mg} / \mathrm{g})\end{array}$ & $\begin{array}{l}\text { Phytates } \\
(\mathrm{mg} / \mathrm{g})\end{array}$ & $\begin{array}{l}\text { Tannins } \\
(\mathrm{mg} / \mathrm{g})\end{array}$ & $\begin{array}{l}\text { Saponins } \\
(\mathrm{mg} / \mathrm{g})\end{array}$ & $\begin{array}{l}\text { Alkaloids } \\
(\mathrm{mg} / \mathrm{g})\end{array}$ \\
\hline Rongai brown & $2.40 \pm 0.03^{*}\left({ }^{* *}\right)$ & $1.00 \pm 0.03^{*}$ & $1.40 \pm 0.03^{*}$ & $0.40 \pm 0.01^{*}\left({ }^{* *}\right)$ & $5.20 \pm 0.01^{\star}$ & $0.20 \pm 0.01^{*}$ & $3.7 \pm 0.02^{*}\left({ }^{* *}\right)$ & $3.9 \pm 0.02^{*}$ \\
\hline Rongai white & $2.11 \pm 0.03\left({ }^{* \star}\right)$ & $1.05 \pm 0.01$ & $1.30 \pm 0.03\left({ }^{* *}\right)$ & $0.50 \pm 0.01$ & $2.80 \pm 0.01\left(^{\star \star}\right)$ & $0.10 \pm 0.01\left(^{\star \star}\right)$ & $4.4 \pm 0.02$ & $3.0 \pm 0.04\left({ }^{* *}\right)$ \\
\hline Highworth black & $2.17 \pm 0.01$ & $1.13 \pm 0.01\left(^{* *}\right)$ & $1.50 \pm 0.02\left(^{* *}\right)$ & $0.60 \pm 0.01\left(^{* *}\right)$ & $6.50 \pm 0.03^{*}\left(^{* *}\right)$ & $0.30 \pm 0.01\left(^{* *}\right)$ & $4.9 \pm 0.02^{*}\left({ }^{* *}\right)$ & $\left.4.1 \pm 0.02^{*}{ }^{* *}\right)$ \\
\hline
\end{tabular}

Most of the values were significant at $\mathrm{p}<0.05$, *Statistical significance among groups using $\mathrm{F}$ test, ${ }^{* *}$ Statistical significance between groups at $\mathrm{P}<0.05$ using ' $\mathrm{t}$ ' test.

added and the mixture was digested in a boiling water bath for $1.5 \mathrm{~h}$ under a reflux air condenser with occasional shaking. The mixture was filtered white hot through a small Buchner funnel. The residue was returned to the flask and redigested for $30 \mathrm{~min}$ with $50 \mathrm{ml}$ alcohol after which the alcohol will be evaporated, adding hot water to replace the alcohol lost. When all the alcohol have been removed, 2 to 3 drops of $10 \% \mathrm{HCl}$ was added and the whole solution was later transferred into a $150 \mathrm{ml}$ volumetric flask. $5 \mathrm{ml}$ of zinc acetate solution and $5 \mathrm{ml}$ of potassium ferrocyanide solution was added, thoroughly mixed to give a homogenous solution.

The flask was allowed to stand for a few minutes, filtered through a dry filter paper and $10 \mathrm{ml}$ of the filtrate was transferred into a separating funnel and the alkaloids present were extracted vigorously by shaking with five successive $30 \mathrm{ml}$ portions of chloroform. The residue obtained was dissolved in hot water and transferred into a Kjeldahl flask with the addition of $0.2 \mathrm{~g}$ sucrose and $10 \mathrm{ml}$ conc. $\mathrm{H}_{2} \mathrm{SO}_{4}$ and $0.02 \mathrm{~g}$ selenium for digestion to a colourless solution. To determine the percentage of $\mathrm{NH}_{3}$ by Kjeldahl distillation method percentage nitrogen got is converted to a percentage total alkaloid by multiplying by a factor of 3.26 .

\section{Statistical analysis}

The experiments were performed in triplicates and the results expressed as mean \pm standard deviation and compared among the groups using the analysis of variance (ANOVA). Statistical difference was also considered between groups using student " $\mathrm{t}$ " test for 2 different means. The value of $p<0.05$ was regarded as significant for statistical comparison in all cases. GraphPad Prism, Version 5.0, San Diego, Ca was the statistical package used.

\section{RESULTS}

The results of the phytochemicals in the raw and aqueous crude extracts of the three varieties of Lablab purpureus are presented in Tables 1 and 2 respectively. In the raw $L$. purpureus seeds, for the trypsin inhibitor activities, the raw Rongai brown has the highest value while the raw Rongai white recorded the least value. The result of the Heamagglutinin content reveals that raw Highworth black had the highest value while raw Rongai white recorded the least. For the cyanogenic glycosides, raw Highworth black has the highest value with raw Rongai white recording the least. For the oxalates, raw Highworth black recorded the highest while raw Rongai white has the least. For the phytates, raw Rongai white had the highest value while raw Rongai brown had the least. For the tannins, raw Rongai brown recorded the highest value while raw Rongai white recorded the lowest value. For the saponins, raw Highworth 
black has the highest value while raw Rongai brown had the lowest value. Lastly, for the alkaloids raw Highworth black had the highest value while raw Rongai white recorded the least value.

In the raw $L$. purpuresus seed varieties, the differences in the phytochemicals among the groups were significant at $\mathrm{p}<0.05$ except for tannins. The differences between the groups were also statistically significant $(p<0.05)$ except in oxalates levels between Rongai brown and Highworth black, in phytate levels between Rongai brown and Highworth black and in tannin in all the three varieties of the $L$. purpureus.

In the aqueous crude extracts of the $L$. purpureus seeds, for the trypsin inhibitors, Rongai brown recorded the highest value while Rongai white had the least value. The result of the Heamagglutinin content reveals that Highworth black had the highest value while Rongai brown recorded the least. For the cyanogenic glycosides, Highworth black had the highest value with Rongai white recording the least. For the oxalates, Highworth black recorded the highest value while Rongai brown had the least. For the phytates, Highworth black had the highest value while Rongai white had the least value. For the tannins, Highworth black recorded the highest value while raw Rongai white recorded the lowest value. For the saponins, Highworth black had the highest value while Rongai brown had the lowest value. Lastly, for the alkaloids Highworth black had the highest value while Rongai white recorded the least value. The differences in the phytochemicals among all the groups were significant at $p<0.05$. The differences between the groups were also statistically significant $(p<0.05)$ except in Haemagglutinin level between Rongai brown and Rongai white varieties.

\section{DISCUSSION}

These trypsin inhibitor values recorded for the raw $L$. purpureus seeds compare favourably with the values obtained for soyabean ranging from 35.30 and 36.90 tiu/mg protein and lima bean ranging from 29.43 to 36.65 tiu/mg protein as reported by Ologhobo (1980) but exceed those obtained for cowpea ranging from 19.60 to $28.20 \mathrm{tiu} / \mathrm{mg}$ protein as reported by Ologhobo and Fetuga (1983). The results are also consistent with that reported for cowpea ranging from 19.0 to $46.7 \mathrm{tiu} / \mathrm{mg}$ protein by (Marconi et al., 1993). The trypsin inhibitors are reported to be one of the major toxic components of legumes (Liener and Kakade, 1980; Akinyele, 1989).

The trypsin inhibitor activities obtained for the raw lablab beans are contrary to the results reported by Lambert (1972) for 26 varieties of cowpea (Vigna sinensis). The authors obtained a range of 15.5 to 23.80 tiu/mg protein and went on to show that environmental and genetic factors affect the trypsin inhibitor activities of legumes. These results compare well with that recorded for some varieties of cowpea TVNU66 having $13 \mathrm{HU} / \mathrm{mg}$ and TVNU226 having $27 \mathrm{HU} / \mathrm{mg}$ as reported by Marconi et al. (1993). The results, however, contradict those of Ologhobo and Fetuga (1983) reporting a mean value of $49.6 \mathrm{HU} / \mathrm{mg}$ protein for cowpea (Vigna unguiculata). However, there appears to be no basis for comparison in as much as the isolation procedures and methods employed differ. Furthermore, the varieties of legumes used and even the environment in which these legumes were grown might have some modifying influences, as reported by Swaminathan and Jain (1973). The variability within species and between locations may be as high as $10 \%$. The occurrence of cyanogenic glycosides in legumes was reported by Okolie and Ugochukwu (1989). The cyanogenic glycosides on hydrolysis yield toxic $\mathrm{HCN}$ (Osuntokun, 1972; Fernando, 1987). The cyanide ions inhibit several enzyme systems, depress growth through interference with certain essential amino acids and the utilization of essential nutrients. The results obtained for the raw lablab beans is lower than that reported by Egbe and Akinyele (1990) reporting $420 \mathrm{mg} / \mathrm{kg}$ cyanogenic glycoside in lima bean (Phaseolus lunatus). Okolie and Ugochukwu (1989) showed total cyanide contents of 381$1095 \mathrm{mg} / \mathrm{kg}$ for seeds of Nigerian varieties of Phaseolus aureus, V. unguiculata, Cajanus cajan and Canavalia gladiatus. These were higher than that reported for raw $L$. purpureus seeds. The differences observed in the varieties of lablab beans and different species of legumes could be attributed to the genetic variations and different chemical composition of the soils on which they were cultivated. Similarly, macro and micro mineral deficiencies in the soil have been found to result in the non-protein nitrogen pool being large and this could result in elevated cyanogenic glycoside levels (Butler et al., 1973).

Oxalates $\left(\mathrm{C}_{2}\right.$ dicarboxylic acid anion) are produced and accumulated in many crop plants and pasture seeds. Oxalates may be present in plants as the soluble salts, potassium, sodium or ammonium oxalate as oxalic acid or as insoluble calcium oxalate. Oxalate is a concern because high oxalate diets can increase the risk of renal calcium absorption. Although there were no values in literature with which to compare the results as regards oxalates in legumes, the results agree with total oxalates reported by Aremu (1989) for Lophira alata $(9.85 \mathrm{mg} / \mathrm{g}$ ), Hyphaene thebaica $(9.57 \mathrm{mg} / \mathrm{g})$ and Bixa orellana $(8.44$ $\mathrm{mg} / \mathrm{g}$ ) which are wild underutilized crop seeds in Nigeria. Phytic acid, a hexaphosphate derivative of inositol is an important storage form of phosphorus in plants. It is insoluble and cannot be absorbed in the human intestines. Phytates can render metals like calcium, iron, zinc and magnesium unavailable into the body by forming insoluble salts with these metals (Edman and Forbes, 1977). However, the results contradict that obtained by Ologhobo (1980), recording a range of 2.90 to $3.25 \mathrm{mg} / \mathrm{g}$ phytate for cowpea.

The results compare well with that recorded for lima beans tannin ranging between 0.32 to $0.93 \mathrm{mg} / \mathrm{g}$ by 
Ologhobo (1980) but it is higher than that recorded for cowpea ranging between 0.24 and $0.58 \mathrm{mg} / \mathrm{g}$ and soyabean varieties ranging between 0.34 and $0.37 \mathrm{mg} / \mathrm{g}$ by Ologhobo (1980). Some studies revealed that the occurrence of tannins in plants are of no nutritional significance unless at very high levels often $10 \%$ or more of the dry weight. Butler (1989) reported that tannins may decrease protein quality by decreasing digestibility and palatability. Egbe and Akinyele (1990) found $0.59 \mathrm{mg} / \mathrm{g}$ tannins in raw lima beans (Phaseolus lunatus). The results obtained for lablab beans suggest that they may very insignificantly affect the nutritional potentials of these legumes.

The result of the levels of saponins in this study is similar to that reported by Achinewhu (1983) recording $11.8 \mathrm{mg} / \mathrm{g}$ saponins for rubber seed (Hevea brasiliensis). The results are also similar to that reported by Osagie et al. (1996), that cowpea contains $11.18 \mathrm{mg} / \mathrm{g}$ saponin. Sodipo and Arinze (1985) reported beans to contain a considerable amount of saponins of about $245.0 \mathrm{mg} / \mathrm{kg}$. While there are suggestions that the consumption of saponins should be encouraged because of their hypocholesterolaemic activity, forage saponins have been reported by Cheeke et al. (1978) to cause toxic and anorexic effects in the rat and swine, thereby limiting the feeding value of high-saponin animal feeds such as alfalfa.

Alkaloids are basic natural products occurring primarily in plants. It has been reported that probably 10 to $20 \%$ of all higher plants contain alkaloids (Wink, 1993). Literature is scarce on the levels of alkaloids in food legumes. Osagie et al. (1996) reported that alkaloid-containing species and varieties may have been eliminated by choice from Nigeria's staple foods because of the bitter taste associated with alkaloids. The values recorded for the alkaloids were low when compared with that of other anti-nutritional factors in lablab beans. This may be an advantage to the nutritional significance of the lablab beans.

The levels of each of the phytochemicals contained in the raw $L$. purpureus seeds were significantly higher than the levels found in the aqueous crude extracts. This could be due to the processes involved in the isolation of the aqueous crude extracts which involves soaking, heating and boiling in water for an extended period of time. It has been reported that different processing methods such as autoclaving, boiling, cooking, fermentation, germination (sprouting), heating and soaking reduce the levels of anti-nutritional factors in plants (Egbe and Akinyele, 1990; Osagie, 1998; Balogun et al., 2001). Akanji et al. (2003) reported that aqueous heating destroyed all haemagglutinins and trypsin inhibitor activities in the seeds of jackbean (Canavalia ensiformis L), dry heating gave percentage losses in the haemagglutinin and trypsin inhibitor activities, while phytate and tannin contents were partially affected by heat treatments. Bawa et al. (2003) also reported that cooking of lablab seeds significantly $(p<0.05)$ decreased the levels of trypsin inhibitor activity, phytic acid, tannin and cyanide. The reduction in the level of the antinutritional factors in the aqueous crude extracts of $L$. purpureus seeds is also similar to report by Esenwah and Ikenebomeh (2008) that soaking and boiling significantly reduced the levels of the anti-nutritional factors (trypsin inhibitor, tannin and phytic acid) of the African Locust Bean (Parkia biglobosa Benth) seed. Abeke et al. (2010) also reported a decrease in the level of trypsin inhibitors, phytic acids, tannins and hydrocyanic acids in the Rongai variety of $L$. purpureus seeds, with increase in duration of cooking.

\section{Conclusion}

It is concluded that $L$. purpureus contain significant concentration of several phytochemicals with good potentials for use as phytomedicines. More work is required to describe the best isolation method for the phytochemicals in LP. The pharmacological effects of the individual phytochemicals in LP also need to be assessed against micro-organisms and parasites. The presence of other secondary metabolites in L. purpureus seeds, apart from those reported in this study also require more indepth study. It is recommended that beyond general phytochemical analysis of plants, further studies should focus on quantitation of phytochemicals and their biosafety evaluation to identify those with the low or high levels.

\section{ACKNOWLEDGEMENT}

The technical assistance of Mr. O. O. Afolabi of the Institute of Agricultural Research and Training (IAR\&T), Moor Plantation, Ibadan is highly appreciated.

\section{REFERENCES}

Abeke FO, Sekoni, AA, Ogundipe SO, Adeyinka IA (2010). Effect of cooking duration on the proximate and some anti-nutritional factors on Rongai variety of Lablab purpureus seeds. $35^{\text {th }}$ Annual Conference of Nigerian Society for Animal Production at the University of Ibadan, Nigeria. pp. 560-562.

Achinewhu SC (1983). The Saponin Content of some Nigerian oilseeds. Qual. Plant Foods Hum. Nutr. 33:3-8.

Adeleke OE, Soetan KO, Fasasi KA (2012). Antimicrobial activities of three varieties of Lablab purpureus seeds. Recent Prog. Med. Plants 32:419-432.

Adeshina GO, Onaolapo JA, Ehinmidu JO, Odama LE (2010). Phytochemical and antimicrobial studies of the ethyl acetate extract of Alchornea cordifolia leaf found in Abuja, Nigeria. J. Med. Plants. Res. 4(8):649-658.

Adu IF, Fajemisin BA, Adamu AM (1992). The utilization of sorghum stover fed to sheep as influenced by urea and graded levels of lablab supplementation. In: Small Ruminant Research and Development in Africa. Proc. of the $1^{\text {st }}$ Biennual Conf. of the African Small Ruminant Research Network, ILRAD, Nairobi, Kenya, 10 to 14, December, 1990. ILCA, Nairobi, Kenya. Rey, B., Lebbie S.H.B and Reynold, R. (editors) pp. 367-374. 
Akanji AM, Ologhobo AD, Emiola IA, Adedeji TA, Adedeji OS (2003). The Effects of processing on Haemagglutinin and other Antinutritional Factors in Jackbean (Canavalia ensiformis L ). Proc. 28th Annu. Conf. Nig. Soc. Anim. Prod. (NSAP) 28:189-193.

Akinpelu DA, Aiyegoro OA, Okoh Al (2009). The bioactive potentials of two medicinal plants commonly used as folklore remedies among some tribes in West Africa. Afr. J. Biotechnol. 8(8):1660-1664.

Akinyele IO (1989). Effects of traditional methods of processing on the nutrient content and some antinutritional factors in cowpeas (Vigna unguiculata). Food Chem. 33:291-299.

Aremu CY (1989). Quantitative estimation of the dietary contributions of phytate, oxalate, and hydrocynanate by six popular Nigerian foodstuffs. Nig. J. Nutr. Sci. 10:79-84.

Balogun TF, Kaankuka FG, Bawa GS (2001). Effect of boiling full-fat soya seeds on its amino acid profile and on performance of pigs. Nig. J. Anim. Prod. 28(1):45-51.

Bawa GS, Tegbe TSB, Ogundipe SO, Dafwang II, Abu EA (2003). The Effect of Duration of cooking Lablab seeds on the level of some Antinutritional Factors. Proc. $28^{\text {th }}$ Annu. Conf. Nig. Soc. Anim. Prod. 28:213.

Bradbury MG, Egan SV, Bradbury JH (1999). Determination of all forms of cyanogens in cassava roots and cassava products using picrate paper kits. J. Sci. Food. Agric. 79:593-601.

Brunner JH (1984). Direct spectrophotometric determination of saponin. Anal. Chem. 42:1752-1754.

Butler GW, Reay PF, Tapper BA (1973). The physiological and genetic aspects of Cyanogenesis in cassava and other plants in proceedings of an interdisciplinary workshop, London, England. 29-30 Jan, Ed. Barry Nestle.

Butler LG (1989). Effects of condensed tannin on animal nutrition in "Chemistry and significance of condensed tannins" R. W. Hemingway and J. J. Karchesy. Eds. Plenum Press, New York, pp. 391-402.

Cheeke PR, Perderson MW, England DC (1978). Responses of rats and swine to Alfalfa saponins. Can. J. Anim. Sci. 58:783-789.

Dawra RK, Makkar HSP, Singh B (1988). Protein binding capacity of microquantities of Tannins. Anal. Biochem. 170:50-53.

Edman JW, Forbes RM (1977). Mineral bioavailability from phytate containing foods. Food. Prod. Dev. 11:46-49.

Egbe AA, Akinyele IO (1990). Effect of cooking on the anti-nutritional factors of lima beans (Phaseolus lunatus). Food Chem. 35:81-87.

El-Mahmood AM, Doughari JH, Ladan N (2008). Antimicrobial screening of stem bark extracts of Vitellaria paradoxa against some enteric pathogenic microorganisms. Afr. J. Pharm. Pharm. 2(5):089094.

Esenwah CN, Ikenebomeh MJ (2008). Processing Effects on the Nutritional and Anti- nutritional contents of African Locust Bean (Parkia biglobosa Benth) seed. Pak. J. Nutr. 7(2):214-217.

Fasset DW (1996). Oxalates.In: Toxicants occurring naturally in foods.National Academy of Science Research Council, Washington D.C, U.S.A.

Fernando R (1987). Plant poisoning in Sri Lanka.In progress in venom and toxin research. Proc. $1^{\text {st }}$ Asia-Pac. Cong. Anim. Plant Microb. toxins. pp. 624-627.

Handa SS, Chawla AS, Maninder K (1989). Hypoglycaemic plants. A review. Fitoterapia 60(3):195.

Henry TA (1973). Organic Analysis of Alkaloids. 6:163-187.

Hostettman K, Martson A (1995). Saponins.Cambridge University Press, Cambride, U.K.

Jaffe W (1979). In I.E. Liener (Ed.): Toxic constituents of plant foodstuffs, pg. 69. Academic Press, Inc. New York.

Lambert AJ (1972). In Bressary R. The protein extraction and nutritive value of the jack bean and protein isolated. Proceedings of a meeting in Riberira Preto. Liener IE (1979). Determination of antitryptic activity of soybean. J. Sci. Agric. 16:602-609.
Liener IE (1979). Determination of antitryptic activity of soybean. J. Sci. Agric. 16:602-609.

Liener IE, Kakade ML (1980). Protease Inhibitors. In: The Lectins: Properties, Functions and Applications in Biology and Medicine (Eds. I.E. Liener, N. Sharon and I.J. Goldstein) Academic Press, New York. pp. 527-552.

Maga JA (1983). Phytate: Its chemistry, occurrence, food interaction, nutritional significance and methods of analysis. J. Agric Food Chem. 30:1-9.

Maiyo ZC, Ngure RM, Matasyoh JC, Chepkorir R (2010). Phytochemical constituents and antimicrobial activity of leaf extracts of three Amaranthus plant species. Afr. J. Biotechnol. 9(21):3178-3182.

Marconi E, Ng NQ, Carnovale E (1993). Protease inhibitors and lectins in cowpea. Food Chem. 47:37-40.

Molan AL, Duncan A, Barry TN, McNabb WC (2000a). Effects of condensed tannins and sesquiterpene lactones extracted from chicory on the viability of deer Zealand Soc. Anim. Prod. 60:25-29.

Molan AL, Hoskin SO, Barry TN, McNabb WC (2000b). Effect of condensed tannins extracted from four forages on the viability of the deer lungworms and gastrointestinal nematodes. Vet. Rec. 147:4448.

Ndukwe IG, Amupitan JO, Isah Y, Adegoke KS (2007). Phytochemical and antimicrobial screening of The crude extreacts from the root,stem bark and leaves of Vitellaria paradoxa (GAERTN F). Afr. J. Biotechnol. 6(16):1905-1909.

Okolie NP, Ugochukwu EN (1989). Cyanide contents of some Nigerian legumes and the effects of simple processing. Food Chem. 32:209216.

Olayinka AA, Okoh A (2010). A preliminary phytochemical screening and in vitro antioxidant activities of the aqueous extract of Helichrysum longifolium. BMC Complementary Altern. Med. 10(21):18.

Ologhobo AD (1980). Biochemical and nutritional studies of cowpea and lima bean with particular reference to some inherent antinutritional factors. Ph.D. Thesis. University of Ibadan. Nigeria.

Ologhobo AD, Fetuga BL (1983). Investigation on the trypsin inhibitor, heamgglutinin, phytic and tannin acid contents of cowpea (Vigna unguiculalata). Food Chem. 12:254.

Osagie AU (1998). Nutritional quality of plant foods, pp. 221-244.

Osagie AU, Muzquiz M, Burbano CO, Cuadrado C, Ayet G, Castano A (1996). Some anti-nutritional constituents in ten staple food items grown in Nigeria. Trop. Sci (U.K). 36:109-115.

Osuntokun BO (1972). Chronic cassava neurotoxicity in Nigerians. J. Plant Food Hum. Nutr. 2:215-221.

Sodipo OA, Arinze HU (1985). Saponin content of some Nigerian foods. J. Sci. Food Agric. 36:407-408.

Soetan KO, Oyekunle MA, Aiyelaagbe OO, Fafunso MA (2006). Evaluation of the antimicrobial activity of saponins extract of Sorghum bicolor L. Moench. Afr. J. Biotechnol. 5(23):2405-2407.

Swaminathan MS, Jain HK (1973). Food legumes in India Agriculture In: Nutritional Improvement of Food Legumes by breeding. Protein Advisory Group, United Nations, New York, pp. 69-82.

Viji MO, Parvatham R (2011). Antimicrobial and cytotoxic profile changes in Leaf, Stem and Root tissues of Withania somniferaPoshita variety. Int. J. Pharmaceut. Biomed. Res. 2(3):81-89.

Wink M (1993). Quinolizidine alkaloids. In 'Methods in plant biochemistry' Academic Press Ltd. 8:197-239.

Zank HM (1991). Chasing the enzymes of secondary metabolism: Plant cell cultures as a pot of goal. Phytochemistry 30(12):3861-3863. Zess. Nauk, UMK. Tornu. 